\title{
Translation Procedures in Translating Proper Names from English into Indonesian
}

\author{
Ni Putu Devi Lestari*, I Made Winaya, I Gst. Ayu Gede Sosiowati \\ English Department, Faculty of Arts, Udayana University \\ [devilestari0317@gmail.com],[made_winaya@unud.ac.id],[sosiowati@yahoo.com] \\ Denpasar, Bali, Indonesia \\ *Corresponding Author
}

\begin{abstract}
Translation procedure is a procedure or a method to translate the unit of language from the source language to the target language. Every linguistic part needs to be translated. It means including the proper names in the literary work. This study is aimed at identifying and analyzing the types of the proper name and their translation procedures in the novel entitled Pembunuhan di Orient Express. The problems in this study are discussed based on the theory of proper name and the theory of the translation procedure by Newmark (1988). The method used to collect the data was documentation method. This study applied the descriptive qualitative method in analyzing the data. The result of the analysis was presented using an informal method. The analysis showed three types of proper names in the data sources. They are people's names, the name of an object, and the geographical term. The translator uses seven methods from 18 translation procedures that were proposed by Newmark (1988).
\end{abstract}

Keyword: proper name, translation, translation procedure, novel

\begin{abstract}
Abstrak
Prosedur dalam penerjemahan adalah sebuah prosedur atau sebuah metode untuk menerjemahkan suatu unit bahasa dari suatu bahasa ke bahasa lainnya. Setiap bagian linguistik harus diterjemahkan. Itu berarti termasuk dengan proper name dalam sebuah karya sastra. Studi ini bertujuan untuk mengindentifikasi dan menganalisis tipe-tipe dari proper name dan tipe prosedur dalam penerjemahan dalam sebuah novel berjudul Pembunuhan di Orient Express. Masalah dalam studi ini dikaji dengan teori proper name dan teori prosedur penerjemahan milik Newmark (1988). Metode yang digunakan untuk mengumpulkan data adalah metode dokumentasi. Studi ini mengaplikasikan metode deskriptif kualitatif dalam menganalisis data. Hasil dari analisis tersebut ditampilkan dengan metode informal. Studi ini menunjukkan tiga tipe proper name yang terdapat dalam sumber data. Itu terdiri atas nama seseorang, nama untuk sebuah objek, dan istilah geografi. Penerjemah menggunakan tujuh metode dari 18 prosedur penerjemahan yang diajukan oleh Newmark (1988).
\end{abstract}

Kata kunci: proper name, terjemahan, prosedur penerjemahan, novel.

\begin{tabular}{lll}
\hline Info Article & & \\
\hline Received & $:$ & $24^{\text {th }}$ December 2019 \\
Accepted & $:$ & $28^{\text {th }}$ October 2020 \\
Published & $:$ & $30^{\text {th }}$ November 2020
\end{tabular}

Published : $30^{\text {th }}$ November 2020 


\section{INTRODUCTION}

Communication is an important aspect of the human being. It is not only about giving and receiving information but also includes the exchange of ideas and culture. This activity can be in the written form called literary work.

Novel is a literary work that enjoyed by many people. It has information about one particular idea or culture through the characters and the setting in the form of the proper name. In order for other people with different language to understand the particular idea and the culture of a country, translation is important to be conducted.

Catford (1965:20) defined translation as the replacement of textual material by equivalent material in the target language. Larson (1984:3) stated that translation is a change of form in the sense of semantic structure. Furthermore, Nida and Taber (1982:2) stated that translation is needed to be applied in every linguistics part, including the proper name in the literary work.

Proper name is a noun or a group of a noun that has individual application. It contains people's name, the name of an object, and the geographical term. It can be found in literary work in which the translator tries to deliver the story through the character and the setting.

Furthermore, the previous studies (Zabir and Haroon, 2018; Eriko, 2016; Majed and Bakri, 2014; Isaiah, 2009, Mussche and Willems, 2010; Nazarabadi and Ghareghani, 2016) showed how proper names in a particular language or country were translated into other languages. It is showed that the proper name is important to be translated.

Nord (2003: 183) stated that translating the proper name can be difficult for the translator since it may be non-descriptive. However, it contains specific information on a particular thing. The translator needs to deliver the information as the same as the source language. In translating the proper name, the translator needs to know about the translation procedure. Translation procedures are needed to transfer the idea in the target language effectively. Molina and Albair (2002: 498) stated that the method or the process to translate the unit of language also can help the people to study how the translation works.

The previous studies (Dewi, 2016; Mashhady, 2015; Farghal and Bazzi, 2017; Affifah, 2012) also showed the translation procedures that were used to translate the word or the proper name from the source language into the target language. It shows how important for the translator to know about translation procedure in translating the proper name.

This study aimed at analyzing the type of proper name in Murder on the Orient Express and the translation procedures that are applied by the translator in the novel.

\section{MATERIAL AND METHOD}

The data were collected from a novel entitled Murder on the Orient Express by Christie (1991) and its Indonesia translation entitled Pembunuhan di Orient Express by Buditjahja (2017). It is a famous novel mystery all the time. Both of the data sources have many interesting proper names that can be analyzed further.

Documentation method and note-taking technique were used to collect the data. The first step was reading the source language and the target language novel. The next step was comparing both data of the novels to find the proper name. Last, it was taking a note on the proper names that were found in the source data.

The collected data were analyzed using descriptive qualitative method. It was done through some stages. The first step began with identifying the types of proper names. The next step was analyzing the translation procedure, which applied in the novel. The result of the analysis were presented using the informal method in the form of description.

\section{THEORETICAL BASIS}

\section{Literature Review}

Yunita (2017) analyzed the methods to translate the proper name and the quality of the translation in Sherlock Homes' novel entitled The Sign of Four. In solving the problem, the theory of Newmark (1988), Fernandes (2006), and Nababan (2003) were used in this study. The result showed that geographical term is the most used proper 
name in the story. Moreover, the translator uses 13 techniques to translate the proper name. The study has a good methodology to analysis the data.

Zarei (2014) analyzed the important of proper name translation. In this study, the theory of Van Coillie (2006), Jaleniauskiene and Cicelyte (2009), and Algeo (1973) were used to explain the reason and the technique of doing the proper name translation. Moreover, the study used a qualitative method to analyze the data. The result showed that there are several techniques of doing translation for the proper name. It is also important to give different aspect to translate a particular proper name. The study has a good explanation.

Sabzalipour (2015) used the theory of Farahzad (1995) and Fernandes (2006) to find out about the translation strategies in translating the proper name. The result showed transliteration is the most used by the translator to translate the proper name. The study is good at classifying the proper name.

Other previous studies, Dweik (2016) and Shirinzadeh and Tengku (2014) tried to use different types of data from a song lyric and student translations. However, both of them do not elaborate on the discussion of the problem very well.

\section{Proper Name}

Algeo (1930: 2) defined a proper name as a name that can be in the form of a noun or a group noun. It has individual application within the text. Furthermore, Newmark (1988:214) stated 3 categories of the proper name. It consists of people's name, the name of an object, and the geographical term.

People's name is a name that related to someone's name. It can be in the form of a full name or only the first name and the last name or the nickname. It also can be in the form of a combination between the name and the honorific title.

The name of an object is a name that related to the non-living thing. It does not belong to people's names and geographical term categories. It can be the name of a book, a play, a company or an organization, a brand and, a proprietary.

The last category is the geographical term. It is a noun related to the name of the earth landscape. It can be the name of a country, a city, a street, a mountain or a river.

Thus, these categories are classified as a proper name in this study.

\section{Translation Procedure}

Newmark (1988: 81) stated that translation procedure is a procedure or a method in translating the smaller unit of language from the source language to the target language. Newmark (1988: 81) also proposed 18 translation procedures. It consists of literal translation, transference, naturalization, cultural equivalent, functional equivalent, descriptive equivalent, synonym, through-translation, shift or transposition, modulation, recognized-translation, translation label, compensation, componential analysis, reduction and expansion, paraphrase, couplets, and note.

These translation procedures are needed to transfer the idea of the proper name into the target language.

\section{RESULT AND DISCUSSION}

This study discusses the types of a proper name and the translation procedure of it. Three types of proper names can be found in the novel. Moreover, the translator uses seven translation procedures in translating the proper name.

\section{Types of the Proper Name}

In this research, three types of proper names are found in the data source. They are people's names, the name of an object, and geographical terms.

\section{People's Name}

This type of proper name can be seen in this following data:

\section{Data 1:}

SL: $\quad$ Arbuthnot did not answer. (1991: 10).

TL: Arbuthnot tidak menjawab. (2017: 22).

Arbuthnot is an older British soldier who has ever served in India. This character is also a passenger in the Orient Express. Since it is related to someone's name in the story, 
this proper name is classified as people's name.

\section{Name of Object}

This type of proper name can be seen in this following data:

\section{Data 2:}

SL: "At what time does Simplon Orient leave?" (1991: 12).

TL: "Pukul berapa kereta Simplon Orient berangkat?” (2017: 27).

Simplon Orient is the name that refers to a specific train in the story. It is a train owned by Compagnie Internationale des Wagons Lits. Because this proper name refers to the non-living thing, it is classified as the name of an object.

\section{Geographical Term}

This type of proper name is seen in this following data:

\section{Data 3:}

SL: "Mais oui. Stamboul, it is a city I have never visited." (1991: 8).

TL: "Mais oui. Istanbul memang kota yang belum pernah kukunjungi." (2017: 27).

Stamboul is the old name of a central city in Turkey around the 19th and 20th centuries. It is a place that passed by the Orient Express in the story. Since it is related to the name of the geographical landscape in the form of a city, this proper name is classified as a geographical term.

\section{Translation Procedures in Translating the Proper Names}

18 translation procedures are purposed by Newmark (1988). The translator uses 7 types of translation procedures to translate the proper name for the source language into the target language. It is shown in the following data:

\section{Transference}

Transference is a translation procedure in which the translator translates the word into the target language as the same as the source language. It is shown in this following data:
Data 4:

SL: "Your name?"

"Edward Henry Masterman." (1991: 49).

TL: "Namamu?"

"Edward Henry Masterman." (2017: 124).

Edward Henry Masterman is a character in Murder on the Orient Express. Since it is related to the name of the character, this proper name is classified as people's name. In transferring this name into the target language, the translator keeps the form the same as the source language. This translation procedure is called transference.

\section{Naturalization}

Naturalization is a translation procedure in which the translator tries to adjust the word from the source language into the appropriate word in the target language. It is shown in this following data:

Data 5:

SL: It was five o'clock on a winter's morning in Syria. (1991: 7).

TL: $\quad$ Musim dingin, pukul lima pagi di Suriah (2017: 13).

In this case, Syria is the name of a country in Western Asia. It is classified as the geographical term. The translator tries to adjust the word in the spelling and pronunciation of the target language, as shown in this process:

Syria /'sıriə/ $\longrightarrow$ Suriah/suriah/

Since there is an adjustment in the spelling and the pronunciation of the target language, this proper name is translated by using naturalization.

\section{Descriptive Equivalent}

Descriptive equivalent is a translation procedure in which the translator adds some words of description in order to transfer the meaning or information in the target language. This translation procedure is shown in the following data: 
Data 6:

SL: "Think of As You Like It, with the Forest of Arden and Rosalind." (1991: 112).

\section{TL: "Ingat saja karya Shakespeare As You Like It dengan 'Rimba Arden'nya and Rosalind itu." (2017: 294).}

As You Like is the name of a play written by Shakespeare in 1595. Since it is the name of a literary work, this proper name is classified as the name of an object. In translating this proper name, the translation uses several words to describe the name. Thus, this translation of proper name uses descriptive equivalent to deliver the idea in the target language.

\section{Through-Translation}

Through-translation is a kind of translation procedure in which the translator translates the intuitional term, the collocation, and the name of the organization into the acceptable form in the target language. It is shown in this following data:

\section{Data 7:}

SL: "You belong to League of Nations?" (1991: 67).

TL: "Anda ditugaskan oleh Liga Bangsa-Bangsa?” (2017: 169).

In this case, League of Nations is the name of an international organization. It has a mission to create world peace. Since it is a non-living in the form of the organization name, this proper name is classified as the name of an object.

In translating this proper name, the translator uses the recognized form in the target language. League of Nations is known as Liga Bangsa-Bangsa in Indonesian. Thus, this proper name uses trough-translation in transferring the idea in the target language.

\section{Translation Label}

Translation label is a translation procedure in which the translator uses an approximate equivalent in the target language in order to translate the new institutional term or collocation. It is shown in this following data:
Data 8:

SL: "We can open our Court of Inquiry without more ado." (1991: 12).

TL: "Kita bisa memulai acara pemeriksaan ini tanpa harus menunggu lebih lama lagi." (2017: 109).

Court of Inquiry is the name of the institutional term. It is related to the process of investigation by the official or the police. In translating this proper name, the translator uses the new and approximate term in the target language. Court of Inquiry becomes acara pemeriksaan as the new term. Thus, this translation procedure is called a translation label.

\section{Reduction and Expansion}

Reduction and expansion is a pair of translation procedure that is proposed by Newmark (1988). The reduction is a translation procedure in which the translator removes one or several parts of the word in the target language. Meanwhile, expansion is a translation procedure in which the translator adds some part in the target language. These translation procedures are shown in these following data:

\section{Data 9:}

SL: "That handkerchief is not mine, Monsieur," said Countess. (1991:115)

TL: "Saputangan itu bukan punya saya, Monsieur." Countess Andrenyi menyela. (2017: 301)

Countess is the honorific title for a woman who holds the rank of count. This proper name refers to the Hungarian couple in the story. Furthermore, this proper name is classified as the people's name.

In translating this proper name, the translator adds the new element in the target language. It is done to make a clear idea of the proper name in the target language. The translator uses expansion to translate Countess into Countess Andrenyi.

A different translation is shown below: 


\section{Data 10:}

SL: $\quad$ Poirot sprang up. "M. Bouc!" (1991: 12).

TL: Poirot cepat-cepat memutar tubuhnya, “Bouc!” (2017: 27).

In this case, M. Bouc stands for Monsieur Bouc. This proper name consists of the honorific title and the name of the character. Since it refers to a specific character in the story, this proper name is classified as people's name.

The translator transfers the idea of this proper name by removing the honorific title in the target language. Although the translator removes one part of the proper name, it does not make the proper name loses its idea. Since Bouc is a Poirot's best friend, losing the honorific title in the target language is acceptable.

\section{Couplets}

Couplets is a kind of translation procedure in which the translator uses two or more types of translation procedure to translate the unit of language. It is shown in the following data:

\section{Data 11:}

SL: Dr. Constantine screwed up his face thoughtfully. (1991: 12).

TL: Dokter Constantine mengerutkan kening, mulai berpikir keras. (2017: 27).

Dr. Constantine stands for Doctor Constantine. Dr. is a written abbreviation for the doctor. This proper name consists of the general term (Doctor) and followed by the name of the person (Constantine). It is classified as people's names in this study.

In translating this proper name, the translator uses two types of translation procedures. The translator uses naturalization to transfer the general term into the target language, as shown in this process:

\section{Doctor /'dpktə(r)/ $\longrightarrow$ Dokter /dokter/}

It is shown that the translator tries to adjust the spelling and the word form in the target language for the general term. However, in translating the name of the person, the translator keeps the proper name as the same as the source language by using transference. Thus, the translator uses naturalization and transference to transfer the idea of one proper name. This translation procedure is called couplets.

\section{CONCLUSION}

Based on the foregoing analysis, two points can be drawn as the conclusion, as follows.

A proper name is a name in which it has individual applications within the text. Three types of proper names can be found in the data source. They are the people's names, the name of an object, and the geographical term.

In translating those proper names, the translator uses seven types from 18 translation procedures that are proposed by Newmark (1988). It consists of transference, naturalization, descriptive equivalent, through-translation, translation label, reduction and expansion, and couplets. Furthermore, the translator can choose the effective procedure or method to transfer the idea of the proper name in the target language.

\section{REFERENCES}

Affifah, Wachidatul. (2012). Translation Methods and Procedures Preference of English Department Students Universitas Airlangga on Translating Fables. Anglicist. Vol. 1.2, 36-42

Algeo, John. (1930). On Defining Proper Names. University of Gainesville.

Al-Quran, Majed and Al-Azzam Bakri. (2014). Why Named? A socio-cultural and Translational View of Proper Names in Jordan. International Journal of Humanities and Social Science, Vol. 4.5, 103-113

Bariki, Isaiah. (2009). Translating African Names in Fiction. Ikala. Vol 14. 23, 43-61

Buditjahja, Gianny. (2017). Pembunuhan di Orient Express. PT. Gramedia Pustaka Utama. 
Catford, J. C. (1965). A Linguistic Theory of Translation. Longman.

Christie, Agatha. (1991). Murder on Orient Express. Harper Collins Publishers.

Dewi, Sintya A. (2016). Procedures of Translation in the English Novel The Hunger Games: Mockingjay into Indonesian. Jurnal Humanis. Vol. $15.1,56-63$

Dweik, Bader S and Al-Sayyed, Sa'ida. (2016). Translating Proper Noun from Arabic into English: Barriers and Procedures. Arab World English Journal (AWEJ) Special Issue on Translation. Vol.5. 181-194.

Farghal, Mohammed and Bazzi, Hiba. (2017). Translation of English fiction titles into Arabic. The International Journal for Translation \& Interpreting Research. Vol. 9. 2, 115-137

Larson, M. (1984). Meaning-Based Translation. University Press of America.

Leech, Geoffery and Svartvik, Jan. (1975). A Communicative Grammar of English. Longman.

Mashhady, H., at all. (2015). Newmark's Procedures in Persian Translation of Golding's Lord of the Flies. International Journal of English Language \& Translation Studies. Vol. 3. $1.57-69$

Molina, L. and Albir, Hurtardo. (2002). Translation Technique Revisited: A Dynamic and Functionalist Approach. Meta: Translators' Journal, Vol. 47, 498-512

Mussche, E. and Willems, K. (2010). Proper Names and Cultural-specific Items in the Arabic Translation of Harry Potter. Meta: Translators' Journal. Vol. 55.3, 474-498

Nazarabadi, Najmeh B. and Ghareghani, F. (2016). Subtitling and Dubbing: A case study of investigating the translation of Proper Nouns in "Rise of Guardians" and "Cloud with a Chance of Meatballs II". Review of Applied Linguistcs Research (RALR). Vol. 2.2, 44-68

Newmark, Peter. (1988). A Textbook of Translation. Prentice Hall.

Newmark, Peter. (1981). Approaches to Translation. Pergamon Press.

Nida, Eugene. A. and Charles R. (1982). The Theory and Practice of Translation. E.J Brill.

Nord, C. (2003). Proper Name in Translating for Children: Alice in Wonderland as a Case in Point. Meta: Translators' Journal. Vol. 48, 182-196

Sabzalipour, M. and Pishkar, K. (2015). Translation Strategies of Proper Nouns in Children's Literature. Journal of Applied Linguistics and Language Research. Vol 2.6, 73-79.

Sato, Eriko. (2016). Proper Names in Translational Contexts. Theory and Practice in Language Studies. Vol. 6.1, 1-10

Shirinzadeh, Seyed Alireza and Tengku Mahadi, Tengku Sepora. (2014). Translating Proper Nouns: A Case Study on English Translation of Hafez's Lyric. Canadian Center of Science and Education. Vol.7.7, 8-16.

Vinay, Paul; Darbelnet, Jean. (1995). Comparative Stylistics of French and English: A Methodology for Translation. John Benjamins Publishing Company.

Yunita, Widiyantari. (2017). Proper Names in Sherlock Homes' Novel 'The Sign of Four' into Its Indonesian Translation. $1^{\text {st }}$ English Language and Literature International Conference. Vol. 1, 394397. 
Zabir, A. and Haroon, H. (2018). Procedures in Translation of Proper Names in Harry Potter and the Goblet of Fire into Malay. GEMA: Journal of Language Studies. Vol. 18. 2. 108123.

Zarei, R. and Norouzi, S. (2014). Proper Nouns in Translation: Should They be Translated?. International Journal of Applied Linguistics and Eenglish Literature. Vol. 3.6, 152-160. 